\title{
Susceptibility of Aedes aegypti larvae to temephos and Bacillus thuringien- sis var israelensis in integrated control
}

\author{
Susceptibilidade de larvas de Aedes aegypti ao tratamento integrado com teme- \\ phos e Bacillus thuringiensis var israelensis
}

\author{
Carlos Fernando S. de Andrande*, Maurício Modolo* *
}

\begin{abstract}
ANDRADE, C.F.S. \& MODOLO, M. Susceptibility of Aedes aegypti larvae to temephos and Bacillus thuringiensis var israelensis in integrated control. Rev. Saúde públ., S. Paulo, 25: 184-7, 1991. The susceptibility of field collected Aedes aegypti larvae was evaluated in terms of median lethal time $\left(\mathrm{LT}_{50}\right)$ and final mortality, when treated with temephos, Bacillus thuringiensis var israelensis as well as mixtures of these two agents. Third instar larvae were shown to be more susceptible than early and late fourth instar ones to the entomopathogen. Survival of some individuals when exposed to temephos suggest possible resistance. Temporal synergism in early fourth instar larvae was detected when they were exposed to mixtures of Bti-temephos. The possibility of this integrated treatment is commented on.
\end{abstract}

Keywords: Aedes. Bacillus thuringiensis, pathogenicity. Cyanamide, toxicity. Mosquito control

\section{Introduction}

Increasing interest has been given to the use of microbial insecticides by Brazilian governmental departments in mosquito control programs in urban areas in recent years. However, the current practice in the campaign against $A$ edes aegypti is still the perifocal and focal chemical insecticide treatment based mainly on a granular formulation of temephos against the larval stage ${ }^{7,8}$.

Such measures have, in recent years ${ }^{8}$, involved the expensive use of many tons of

organophosphorous compunds. Furthermore, they have increased the possibility of the development of resistance to such compounds, already detected all over the world, as also to temephos in Caribbe and neighboring countries 9 11,12 .

The high larvicidal activity against mosquitoes of products based on Bacillus thuringiensis var. israelensis $(\mathrm{Bti})$ has been frequently reported and the feasibility of its use in Brazil has been pointed out ${ }^{4,10}$.

\footnotetext{
* Departamento de Zoologia do Instituto de Biologia da Universidade Estadual de Campinas (UNICAMP) Campinas, SP - Brasil.

** Superintendência de Controle de Endemias (SUCEN) Campinas, SP - Brasil.

Separatas/Reprints: C.F.S. Andrade - UNICAMP - Caixa Postal 6109 - 13083 - Campinas, SP - Brasil.

Publication supported by FAPESP. Process Medicne 90/4602-1.
}

In order to achieve efficient mosquito control and avoid the development of resistance, the World Health Organization has recommended the taking of such measures as the mixing, rotation or successive use of insecticides ${ }^{9}$. Our previous research into the use of temephos in association with Bti Against Culex quinquefasciatus in sewage showed promising results both under laboratory and field conditions ${ }^{1}$.

The present study was undertaken to assess the level of susceptibility of a natural Ae. aegypti larval population under laboratory conditions, both to temephos and to a commercial Bti formulation, as well as to mixtures of these two larvicides.

\section{Material and Method}

Locality and age of test insect: Ae. aegypti larvae were obtained from natural breeding sites such as tyres, discarded tins, cans and flower-pots. Collections were carried out in an urban area (Manoel da Nobrega district) of Campinas, State of S. Paulo, Brazil, during April 1987.

In the laboratory larvae were transferred to petri dishes and separated into third, early fourth and late fourth instars, according to head/body size relation. Young larvae were discarded owing to the difficulty of confirming their identification.

Susceptibility tests: Larvae were treated in 
small polypropylene containers each holding two liters of commercial spring water $\left(\right.$ Fontagua ${ }^{\mathrm{R}}$ ) in such a way as to present a surface area of about $500 \mathrm{~cm}^{2}$ and $4.5 \mathrm{~cm}$ in depth. No additional food was offered and the larvae were kept for ca. $1 \mathrm{~h}$ before treatment to permit acclimatization. After this period, sporadic abnormal larvae were replaced by normal ones.

Two replicates of 29 larvae each were used for Bti, temephos and mixture treatments. Another two replicates of 25 untreated larvae were maintained as controls. The calculated amount of larvicide was added to each box in $5 \mathrm{ml}$ of stock solution and homogenated by gently stirring with a glass rod. Vectobac $12 \mathrm{AS}^{\mathrm{R}}$, an aqueous suspension formulation of $\mathrm{Bti}$ containing 1,200 Ae. aegypti International Toxic Units (ITU)/mg and Abate $500-\mathrm{E}^{\mathrm{R}}$ emulsifiable concentrate containing $50 \% \mathrm{w} / \mathrm{v}$ of temephos were utilized.

The number of dead larvae and the water temperature were recorded at progressive time intervals until complete mortality or pupation was reached. Susceptibility was compared in terms of final mortality $18 \mathrm{~h}$ post-treatment and median lethal time $\left(\mathrm{LT}_{50}\right)^{4}$ calculated by log-probit regression using a $\mathrm{PC}$-microcomputer and a BASIC programme. The differences between two LTs $s_{50}$ was considered significant or otherwise depending on overlapping existence of their confidence limits $(p<0,05)$.

Table 1. Median lethal time ( $\left(T_{50}\right)$, confidence limits $(C L)$ and final mortality for concentrations of Bacillus thuringiensis var. israelensis used against third $\left(L_{3}\right)$ and fourth $\left(L_{4}\right)$ instar larvae of Aedes aegypti.

\begin{tabular}{lccccc}
\hline $\begin{array}{l}\text { INSTAR } \\
\begin{array}{l}\text { Concentration } \\
\text { (ITU/I) }\end{array}\end{array}$ & $\mathrm{L}_{3}$ & $\mathrm{~L}_{3}$ & $\mathrm{~L}_{4}$ early & $\mathrm{L}_{4}$ early & $\mathrm{L}_{4}$ late \\
\hline $\mathrm{LT}_{50}(\mathrm{~min})$ & 261.2 & 235.0 & 391.4 & 298.0 & 362.1 \\
Lower CL & 251.7 & 220.1 & 379.2 & 291.5 & 355.4 \\
Upper CL & 271.1 & 250.9 & 404.1 & 304.7 & 369.0 \\
Mortality (\%) & 100 & 100 & 100 & 100 & 96.8 \\
\hline
\end{tabular}

\section{Results}

The mean water temperature recorded during the experiment was of $17.8 \pm 1.2^{\circ} \mathrm{C}$. No mortality was observed among the control group, thus eliminating the need for the application of any corrective formula.

Table 1 presents the results in terms of $\mathrm{LT}_{50}$ and final mortalities of Ae. aegypti larvae treated with Bti. Third instar $\left(\mathrm{L}_{3}\right)$ larvae were shown to be more susceptible to Bti than fourth instar ones $\left(\mathrm{L}_{4}\right)$. A significantly shorter time, to cause $50 \%$ mortality of $\mathrm{L}_{3}$ larvae was obtained for both concentrations, though the same total mortality was achieved in both $\mathrm{L}_{3}$ and early $\mathrm{L}_{4}$ larvae. The relatively high $\mathrm{LT}_{50}$ obtained among late $\mathrm{L}_{4}$ larvae to $5,000 \mathrm{ITU} / \mathrm{l}$ as well as the partial final mortality indicate their low susceptibility to Bti. The regression lines and the angular coefficients for Bti treatment against $\mathrm{L}_{3}$ and $\mathrm{L}_{4}$ larvae can be found in Figure 1 .
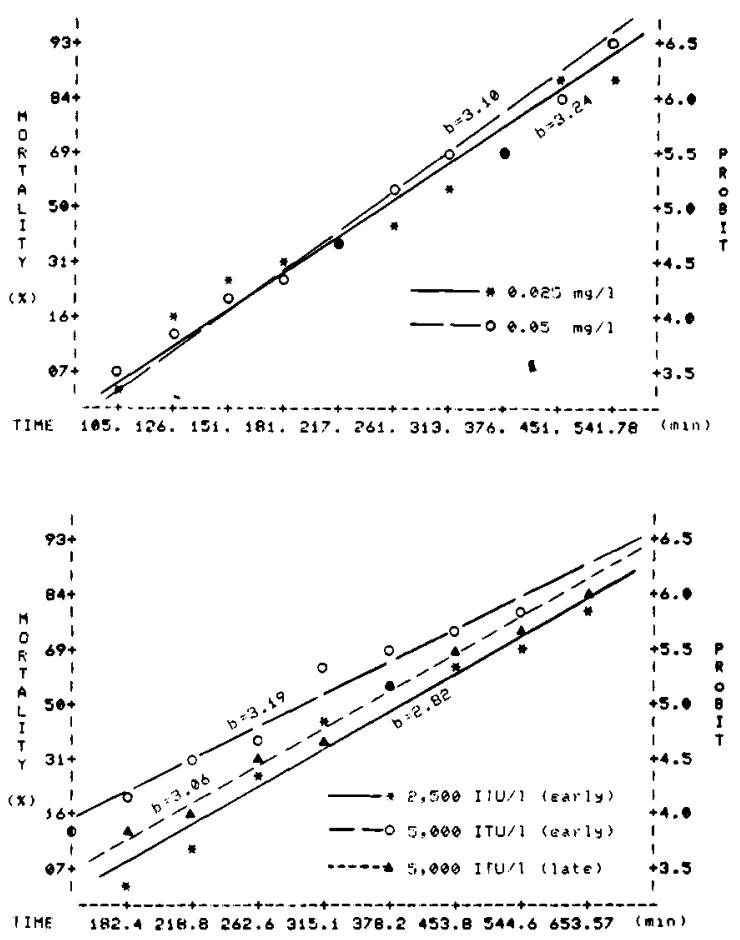

Figure 1. Time-mortality curves for 2 concentrations of Bacillus thuringiensis var. israelensis used against third (A) as well as early and late forth instar (B) Aedes aegypti larvae ( $b=$ angular coefficient).

Early $\mathrm{L}_{4}$ larvae presented $\mathrm{LTs}_{50}$ to temephos near to $4 \mathrm{~h}$ with a significant variation between the two concentrations. Although temephos $\mathrm{LTs}_{5_{0}}$ were shown to be lesser then those of $\mathrm{Bti}$ against early $L_{4}$ larvae, a greater survival rate was observed among the former treatments, resulting in $96.4 \%$ and $89.8 \%$ as final mortalities, respectively, after $18 \mathrm{~h}$ (Table 2). Figure 2 presents the regression lines and the angular coefficients for early $\mathrm{L}_{4}$ larvae treated with the chemical insecticide.

Mixtures of temephos and Bti were evaluated against early $\mathrm{L}_{4}$ larvae in two different concentrations. The higher mixture was equivalent to the sum of the lowest concentrations of the two larvicides when evaluated separately. The other was equal to $1 / 2.5$ of this mixture. The . 
Table 2. Median lethal time ( $\left.L T_{50}\right)$, confidence limits $(C L)$ and final mortality for 2 concentrations of temephos used against early fourth instar Aedes aegypti larvae.

\begin{tabular}{lcc}
\hline Concentration $(\mathrm{mg} / \mathrm{l})$ & 0.025 & 0.05 \\
\hline $\mathrm{LT}_{50}(\min )$ & 256.4 & 244.6 \\
Lower CL & 249.3 & 240.7 \\
Upper CL & 263.8 & 248.7 \\
Mortality $(\%)$ & 96.4 & 89.8 \\
\hline
\end{tabular}

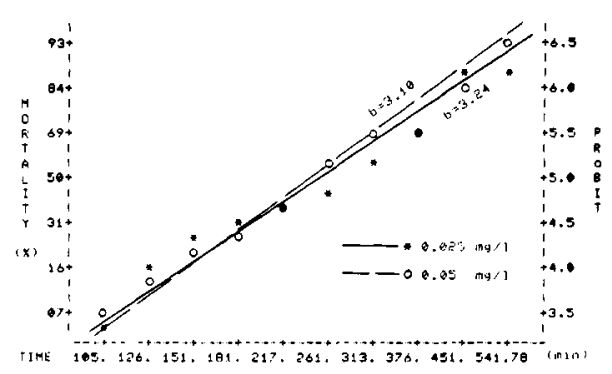

Figure 2. Time-mortality curves for 2 concentrations of temephos used against early $L_{4}$ Aedes aegypti larvae $(b=$ angular coefficient).

Ae. aegypti larvae treated showed low susceptibility to the lower mixture resulting in a $\mathrm{TL}_{50}$ close to $6.2 \mathrm{~h}$ and a final mortality of $91.2 \%$. For the higher mixture the $\mathrm{TL}_{50}$ was close to $3.2 \mathrm{~h}$ with a final mortality of $98.4 \%$ (Table 3). Regression lines and angular coefficients for Bti and temephos mixtures used against early $\mathrm{L}_{4}$ larvae are shown in Figure 3.

Table 3. Median lethal time $\left(\mathrm{LT}_{50}\right)$, confidence limits $(\mathrm{CL})$ and final mortality for 2 mixtures of Bacillus thuringiensis var. israelensis with temephos used against early fourth instar Aedes aegypti larvae.

\begin{tabular}{lcc}
\hline Concentrations & & \\
Temephos $(\mathrm{mg} / \mathrm{l})$ & $0.01+$ & $0.025+$ \\
Bti $(\mathrm{ITU} / \mathrm{l})$ & 1,000 & 2,500 \\
\hline $\mathrm{LT}_{50}(\mathrm{~min})$ & 372.8 & 194.6 \\
Lower CL & 363.3 & 188.9 \\
Upper CL & 382.6 & 199.3 \\
& & \\
Mortality (\%) & 91.2 & 98.4 \\
\hline
\end{tabular}

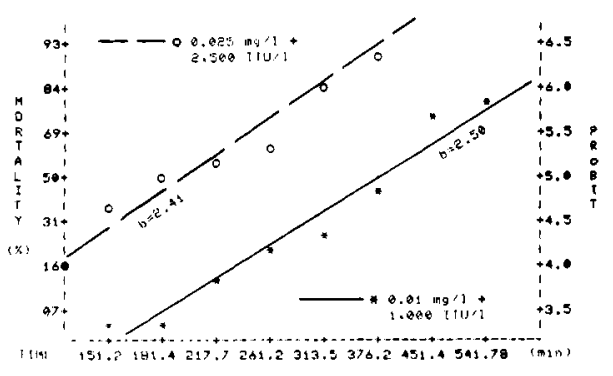

Figure 3. Time-mortality curves for 2 mixtures of temephos and Bacillus thuringiensis var. israelensis used against early $L_{4}$ Aedes aegypti larvae ( $b=$ angular coefficient).

\section{Discussion}

The rapid mode of action of Bti formulations against $A e$. aegypti larvae has been reported ever since the discovery of this entomopathogen. Very high experimental concentrations such as 900,000 ITU/l against $L_{3}$ larvae or 12,000 ITU/1 against $\mathrm{L}_{4} A$ Ae. aegypti larvae are able to cause $\mathrm{LTs}_{50}$ in time intervals as short as 12 or $25 \mathrm{~min}$., respectively ${ }^{5,6}$.

In the present work, Ae. aegypti larvae present $\mathrm{LTs}_{50}$ ranging from ca. 4 to $6.5 \mathrm{~h}$ when subjected to field recommended doses of Bti, and except for those in late fourth instar no surviving larvae were recorded. The differences observed in larval susceptibility among different larval ages may be due to a greater filtration rate in early $\mathrm{L}_{4}$ larvae, as compared with those in third or late fourth instars. Such results permit us to reinforce existing recommendations as to a criterious choice of aged larvae and the use of those in early $\mathrm{L}_{4}$ when seeking to compare susceptibility to larvicides with "per os" effect.

According to the tentative diagnostic dosages proposed by the World Health Organization (Brown) ${ }^{3}$, survival of any Ae. aegypti larvae from exposure to $0.02 \mathrm{mg} / \mathrm{l}$ of temephos would indicate the possibility of resistance among the population tested. In the present work survival both to 0.025 and $0.05 \mathrm{mg} / \mathrm{l}$ was obtained, thus making full multiple-concentration tests imperative to confirm the level of resistance among Brazilian populations of Ae. aegypti larvae.

The two mixtures of larvicides evaluated showed a significant antecipation in the $\mathrm{LTs}_{50}$ for early $\mathrm{L}_{4}$ larvae. The higher mixture provoked $50 \%$ mortality one hour earlier than the chemical insecticide alone and 3.3 hours earlier than that caused by the bacteria alone. The lower mixture, though 2.5 times less strong, was sufficient to cause $50 \%$ mortality in $6.3 \mathrm{~h}$ and a final mortality of up to $90 \%$. Such a performance may be considered equivalent in terms of $\mathrm{LT}_{50}$ to $\mathrm{Bti}$ alone when evaluated at 2,500 ITU/1. This implies a classic temporal synergism, as described by Benz ${ }^{2}$.

The integration of biological and chemical insecticides to control mosquito larvae may have as its main advantages the more rapid onset of death, thus controlling $\mathrm{L}_{4}$ larvae which otherwise would escape control starving for pupation, as well as permitting more economical treatment. As an additional advantage, the integrated control may also reduce the normal pressure towards the resistance selection to a routinely used chemical insecticide. According to pest management precepts, the monitoring of resistance development is in any case 
imperative. The use of sub-doses of more than one active ingredient in integrated control must take a double resistance risk into account, and a good monitoring programme must always be undertaken.

ANDRADE, C.F.S. \& MODOLO, M. Susceptibilidade de larvas de Aedes aegypti ao tratamento integrado com temephos e Bacillus thuringiensis var israelensis. Rev. Saúde públ., S. Paulo, 25: 184-7, 1991. A susceptibilidade de larvas de Aedes aegypti coletadas no campo foi avaliada em termos do tempo letal mediano ( $T L_{50}$ ) e da mortalidade final, quando tratadas com temephos, Bacillus thuringiensis var israelensis ou misturas desses dois agentes. As larvas de terceiro estádio mostraram-se mais suceptíveis ao patógeno do que aquelas no início ou no fim do quarto estádio. A sobrevivência de alguns indivíduos aos tratamentos com temephos permite sugerir a possibilidade de resistência. Foi detectada a existência de sinergismo temporal, quando larvas no início do quarto estádio foram tratadas com as misturas do Bti com o temephos. A possibilidade do tratamento integrado é comentada.

Descritores: Aedes. Bacillus thuringiensis, patogenicidade. Cianamida, toxicidade. Controle de mosquito.

\section{References}

1. ANDRADE, C.F.S. Ecologia de supressão de populaçð̃es de culicídeos e simulídeos. Campinas, 1989. [Tese de Doutorado - Instituto de Biologia da UNICAMP]

2. BENZ, G. Synergism of micro-organism and chemical insecticides. In: Burges, H.D. \& Hussey, N.W., eds. Microbial control of insects and mites. New York, Academic Press, 1971. p. 237-56.
3. BROWN, A.W.A. Insecticide resistance in mosquitoes: a pragmatic review. J. Amer. Mosquito Control Ass., 2: 123-40, 1986.

4. HABIB, M.E.M. \& ANDRADE, C.F.S. Bactérias entomopatogênicas. In: Alves, S.B., coord. Controle microbiano de insetos. São Paulo, Ed. Manole, 1986. p. 127-70.

5. IGNOFFO, C.M. et al. Susceptibility of Aedes aegypti to four varieties of Bacillus thuringiensis. Mosquito News, 40: 290-1, 1980.

6. LAHKIN-TSOROR, L. et al. Lavicidal activity of Bacillus thuringiensis subsp. israelensis, serovar H-14 in Aedes aegypti: histopathological studies. J. Invertebr. Pathol., 41: 104-16, 1983.

7. LIMA, M.M. \& ARAGÃO, M.B. Tratamento focal e perifocal contra Aedes aegypti. Cad. Saúde públ., 3: $142-7,1987$

8. MARQUES, A.C. Sobre a viabilidade atual da erradicação do Aedes aegypti no controle da febre amarela no Brasil. Rev. bras. Malar., 37: 37-46, 1985.

9. ORGANIZACIÓN MUNDIAL DE LA SALUD. Comite de Expertos en Biologia de los Vectores y Lucha Antivectorial, Ginebra, 1980. Resistencia de los vectores de enfermedades a los plaguicidas; $50^{\circ}$ informe. Ginebra, 1980. (Serie de Informes Técnicos, 655).

10. RUAS NETO, A.L. \& OLIVEIRA, C.M. Controle biológico de culicídeos e simulideos: inseticidas bacterianos. Rev. bras. Malar., 37: 61-75, 1985.

11. TAUIL, P.L. O problema do Aedes aegypti no Brasil. Rev. Soc. bras. Med. trop., 19: 1-3, 1986.

12. TONN, R.J. et al. Aedes aegypti: yelow fever and dengue in the Americas. Mosquito News, 42: 197-203, 1982.

Received in 21/9/1990 Reviewed in $27 / 2 / 1991$ 